Т. М. Мішеніна

\title{
СТРУКТУРНО-СЕМАНТИЧНІ ОСОБЛИВОСТІ ФАУНО- І ФЛОРОНІМІВ У СУЧАСНІЙ УКРАЇНСЬКІЙ МОВІ
}

Мішеніна Т. М. Структурно-семантичні особливості фауно- i флоронімів у сучасній українській мові.

У статті розглядається питання про залежність структур і семантики посесивних конструкцій від складу компонентів посесивного зв'язку, про роль цих компонентів у визначенні трансформаційного вектору посесивних одиниць.

Ключові слова: посесивність, семантичний компонент посесивного зв'язку, трансформаційний аналіз.

Мишенина Т. М. Структурно-семантические особенности фауно- и флоронимов в современном украинском языке.

В статье рассматривается вопрос о зависимости структуры и семантики поссесивнных конструкций от состава компонентов поссесивной связи, о роли этих компонентов в определении трансформационного вектора поссесивных единиц.

Ключевые слова: поссесивность, семантический компонент поссесивной связи, трансформационный анализ.

Mishenina T. M. Structure and semantic peculiarities of founa- and floranymies at the morden Ukrainian language.

The article investigates the question of depening the structure and semantic of constructions of possessiveness on the possessivene constituents. It also examines in defining the transformational models of possessivene units.

Key words: possession, semantic constituent of possessive connection, transformational analysis.

Можливості мовної одиниці передавати певний семантичний i структурно-синтаксичний зміст зумовлюють вибір тієї чи тієї одиниці мовцем у процесі мовлення й визначають сферу іiі вживання. Функціональний аналіз застосовано в дослідженнях семантичних категорій темпоральності, модальності, локативності, аспектуальності, оцінки тощо. Сукупність засобів вираження розуміємо як певний простір, у якому виділяється ядро й периферія. Базова одиниця реалізує в реченні значення категорійної домінанти щодо формального вираження позиції всіх учасників ситуації. Посесивні одиниці перебувають у дериваційних узаємозв'язках.

Звідси, відповідно, актуальним є визначення національно-культурної специфіки назв представників флори і фауни - дериватів конструкцій органічної належності. Назви відображають структуру знань і уявлень українського народу про флоро- і фауноніми, узаємодію коду 3 іншими культурними кодами в українській мовні картині світу.

Мета статті полягає у з'ясуванні зумовленості структурносемантичних особливостей флоро- і фаунонімів в українській мові. 
У сучасному мовознавстві категорія посесивності розглядається як одна з універсальних понятійних категорій мови, основним значенням якої $\epsilon$ визначення назви об'єкта, що перебуває у відношенні володіння 3 суб' єктом (особою чи предметом).

Найзагальніше значення посесивних конструкцій $\epsilon$ абстрактним i позначає відношення між об'єктами [6, с. 4]. Аналіз конкретних систем посесивних значень, що реально репрезентуються в різних мовах дозволяє визначити посесивність як семантико-синтаксичну універсалію, яка означає зв'язок між незалежною субстанцією та залежним об'єктом.

При моделюванні системи посесивних відношень обов'язковим $є$ визначення напряму зв'язку, ступеня його тривалості. Характер зв'язку (залежно від ситуації) дозволяє трактувати посесивність як категорію, що позначає єдине фізичне і / чи функціональне ціле. Посесивне відношення усвідомлюється мовним менталітетом і репрезентується на лексичному, морфологічному або синтаксичному рівнях.

Згідно з концепцією функціональної граматики виділяють граматичну форму, яка інтегрує найбільш характерні ознаки аналізованої семантичної сфери [4, с. 99]. Типова структура, що грунтується на семантичній категорії посесивності, репрезентує той аспект «загальної ситуації», який розкриває й характеризує посесивні відношення. Подібна структура займає центральне місце в синтаксичному змісті речення, а предикативна ознака володіння інтерпретуємо як наявність (наявність предмета у сфері володіння).

На основі аналізу посесивних відношень дослідники (О. Бондарко, О. Головачова, В. Топоров) розглядають категорію посесивності як концентричну (антропоцентричну) структуру, центром якої є людина. Ї̈̈ духовне ядро, тіло, зовнішня реальність усвідомлюється як «посесивний простір». У сучасній лінгвістиці антропоцентризм визначається як основа взаємозв'язку мови та мислення. Антропологічна модель розглядає мовні явища у проекції на вищий рівень організації мови, який передбачає обов'язкову присутність людини. Про антропоцентричні механізми мови можна говорити як на рівні судження, так і на рівні суб'єкта і предиката вторинної номінації. На рівні суб'єкта антропоцентризм полягає в самому виборі першого, тобто в заданій темі, яка підлягає концептуалізації. Суб'єкт вторинної номінації належить в основному до сфери людини та до гуманізованих сфер досвіду (абстрактні поняття).

Ми зазначали, що за спрямованістю зв'язку відношення посесивності може характеризуватися як відношення «входження» й відношення «включення». Об'єкт, залучений до посесивного простору, представлений як невідокремлювана частина посесора. Подібні зв'язки характеризують неорганічну належність. Наше бачення невідчужуваності грунтується на тому, що посесивні відношення виникають між незалежною субстанцією (суб'єктом) і залежною (об'єктом) - заданою, обов'язковою складовою 
посесора. 3 цієї позиції функціональні, родинні зв'язки на рівні особа особа визначаємо як ознаку відчужуваної належності. Неорганічна належність характеризує об'єкт як окремий, відчужуваний від посесора. Об'єкт, що входить до сфери посесора, становить дискретну одиницю зовнішньої реальності і є відчужуваною частиною посесора.

Як уже зазначалося, основними засобами вираження значення володіння та його семантичних варіантів учені вважають предикативні конструкції, у яких знаходять формальне вираження позиції посесора, об’єкта та предикативної ознаки володіння. До лексичних засобів вираження посесивності науковці зараховую складні іменники та прикметники, які в семантичній структурі містять сему володіння. Складні, присвійні й деякі якісні прикметники за умови препозиції утворюють атрибутивні посесивні конструкції. Складні прикметники, що характеризують фізіологічний стан, $є$ показовими в сучасній українській мові. Пор.: Хлопець має сині очі - Синьоокий хлопещь. Менш уживаними $є$ складні іменники: синьоок, кривоніс. Якісні прикметники з посесивним значенням указують на об'єкт володіння (зубатий, вусатий, горбатий) або позначають ознаки суб'єкта (багатий, бідний, розумний).

Одиниці всіх рівнів містять сему, яка передбачає зв'язок між двома предметами і може реалізуватися як у лексичних одиницях, визначаючи сам принцип номінації об'єкта, так і на синтаксичному рівні. Тому виокремлення базової моделі уможливлює систематизацію семантичних компонентів посесивних відношень, які своєрідно групуються в конструкціях певного семантичного різновиду, а також зумовлюють трансформаційний процес через актуалізацію певних компонентів посесивних відношень.

У публікації аналізуємо структурно-семантичні особливості дериватів конструкцій органічної належності в соціокультурному контексті. Одним iз пріоритетних напрямів сучасного українського мовознавства $€$ аналіз мови як найважливішого засобу вираження етносвідомості, національного характеру, духовної культури народу, його картини світу. Домінування в сучасній світовій лінгвістиці когнітивно-дискурсивної парадигми спрямовує такі дослідження в царину лінгвоконцептології, метою якої $є$ опис організації та способів вербалізації концептів як складників свідомості, носіїв культурно значущої інформації певного етносу.

В україністиці підгрунтям концептуального аналізу стали численні розробки фрагментів мовної картини світу українського народу (С. Єрмоленко, В. Жайворонок, В. Калашник, Ю. Карпенко, В. Скляренко, В. Ужченко й інші).

У руслі нашого дослідження визначальним є інтерпретація назв на позначення представників флори i фауни - дериватів конструкцій iз семантикою органічної належності (посесивний зв'язок «неособа будова»). 
Основним методом подібних досліджень є концептуальний аналіз, за допомогою якого здійснюється моделювання концептів як ментальнопсихонетичного комплексу. Метод передбачає когнітивноономасіологічний аналіз, що дає змогу встановити зв'язки ономасіологічних структур українських назв рослин i тварин зі структурами знань про означене, зважаючи на організацію концептів в етносвідомості. Використовуваною $\epsilon$ методика словотворчого й етимологічного аналізу. Специфіка нашого дослідження визначає посилену увагу до дериваційної парадигми одиниць, що дозволяє здійснити всебічний структурно-семантичний аналіз.

Мотивація назв визначається за типом фрагментів концептуальних структур, обраних мотиваторами позначень. Моделювання цих структур ураховує методику про позиційного аналізу, розроблену рольовою граматикою й семантичним синтаксисом i використовувану для встановлення об'єктивно-логічної інформації про флоро- і фауноніми у свідомості; методику концептуальної метафори, упровадженої в когнітивній семантиці.

Задля визначення способів вербалізації флоро- і фауноконцепта в українській картині світу i специфіки використання знаків коду в концептуальних сферах застосовуємо контекстуальний, компонентний, текстово-інтерпретаційний, лінгвостилістичний та архетип ний аналіз.

Концептуальне моделювання й інтегрований опис значущих $\mathrm{y}$ культурному сенсі для українського народу концептів етносвідомості у проекції на диференціацію наукової, наївної й поетичної картин світу; сприяє поглибленню знань про організацію ментального лексикону і його зв'язок із національною свідомістю, характером, культурою народу.

Термін «концепт» у сучасній лінгвістиці розглядається неоднозначно: суперечливими й дискусійними $є$ питання співвідношення концепту, поняття та значення, вербалізації концепту, узаємодії індивідуального й етнічного в концепті, його структури, психічної природи, способу та методик моделювання й опису. Базовим $\epsilon$ розуміння концепту як інформаційної структури, що відображає знання й досвід людини; оперативної змістовної одиниці пам'яті, ментального лексикону, концептуальної системи й мови мозку, усієї картини світу, відтвореної в людській психіці (О. Кубрякова).

Концепт не обмежується лише мисленнєвими структурам, а й залучає різні пізнавальні механізми свідомості, які забезпечують накопичення концептуальної інформації: відчуття, почуття, образи, інтуїцію, трансценденцію та колективне позасвідоме.

Ознаками концепту є: неізольованість, тобто зв'язаність 3 іншими концептами; відкритість як невичерпність їхнього змісту; наявність їх у межах структурованих концептуальних сфер, які $є$ фоном концепту; цілісність i несувора структурованість; динамізм i креативність як здатність змінюватися, поповнюватися новим знанням, уточнюватися. 
Способом репрезентації концепта $є$ знаки природної мови, які нашаровуються на концептуальну інформацію й інтегруються 3 нею в мовно-мисленнєвій діяльності. Отримавши мовне позначення, концепт формує семантику мовних одиниць, яка актуалізується в тому чи тому аспекті в певній ситуації використання знака. Модель ментальнопсихонетичного комплексу у своїй структурі містить пропозиційний компонент, що належить мисленнєвий сфері свідомості й корелює 3 іншими психічними функціями, образами й архетипами колективного позасвідомого (О. Селіванова). Пропозиційний компонент є системою пропозицій - мисленнєвий аналогів ситуацій, учасниками яких $\epsilon$ представники флори i фауни, що передають відносно об'єктивну й несуперчливу інформацію, позначену мовними одиницями у прямих значеннях. Асоціативно-термінальна частина формується через переінтерпретацію знань у термінах інших концептуальних сфер на підставі мисленнєвої аналогії, образного сприйняття об'єкта.

Когнітивно-ономасіологічний аналіз мотивації української флоро- i фаунолексики складається 3 двох етапів: інтерпретації ономасіологічних структур назв i моделювання структур знань про позначене. Ономасіологічні структури похідних флоро- і фаунонімів побудовані за різними моделями і представлені простими дериватами, композитами, юкстапозитами і сполуками.

Інтерпретація ономасіологічних структур передбачала 3'ясування концептуального статусу ономасіологічних ознак, визначення ономасіологічного базису (напрям деривації вихідних посесивних одиниць). Моделювання структур знань про позначене грунтується на організації ментально-психонетичного комплексу. Проектування української флоро- i фаунолексики на цю модель дало змогу реконструювати відповідні фрагменти концептів у поєднанні засобів їх презентації в науковій i наївній картинах світу. Наукова картина флори i фауни відображена в номенклатурних назвах, прийнятих у польових визначниках, а наївна - народними назвами.

Диференціація типів мотивації залежить від статусу мотиватора у структурі знань про позначене. Пропозиційна мотивація визначає реконструкцію об'єктивних знань про представників флори і фауни, які містять: класифікаційних поділ на ряди, родини й види; відповідні ситуації, пов'язані з життєдіяльністю представників флори і фауни, особливостями забарвлення й будови тіла тощо.

Флоро- і фауноконцепти в українській етносвідомості є однією iз ключових, культурно маркованих констант, що формується внаслідок узаємодії різних пізнавальних механізмів: сприйняття флоро- $\mathrm{i}$ фаунолексем переважно зором і слухом, фіксації образів, оброблення цієї інформації мисленнєвою сферою, формування стереотипів й усталених оцінок на базі архетипів колективного позасвідомого й наївної картини 
світу, а аткож детальної категоризації в науковій картині світу. Характеристика мовних засобів репрезентації концептів здійснюється на підставі когнітивно-ономасіологічного аналізу мотивації українських флоро- і фаунонімів.

Структурно-семантичні особливості посесивних конструкцій дозволяють декодувати їхнє концептуальне переосмислення. На основі спостереження над мовним матеріалом частини тіла посесора можна поділити на абсолютно та відносно невідчужувані. Якщо абсолютно невідчужувані об'єкти є обов'язковими i водночас унікальними в посесивному просторі суб'єкта, то відносно невідчужувані необов'язковими. Для конструкцій з абсолютно невідчужуваним об'єктом обов'язковим $\epsilon$ атрибутивний структурно-семантичний поширювач, який виражає ознаки за розміром, формою та кольором. Структури моделі $\mathrm{C}-\Pi-\mathrm{O}$ - Loc репрезентують зв'язок фізичного та психічного станів особи. У подібних конструкціях предикати виражаються тематичними дієсловами, що характеризують виявлення буття; локатив - іменниками на позначення фізичного органу або частини тіла. При реалізації моделі $\mathrm{C}-\Pi$ - Atr - O конструкції містять інформацію про чітку відповідність між станом i зовнішнім виглядом суб'єкта. Атрибут виражається прикметником на позначення емоціональних характеристик, моральних та вольових якостей особи.

Посесивні конструкції трансформуються у складні іменники або субстантивні власне словосполучення залежно від функції такого компонента посесивного значення, як постійність / тимчасовість; а також характеру зв'язку між посесором та об'єктом, де об'єкт кваліфікується як абсолютно чи відносно невідчужуваний. Оскільки структурною особливістю конструкцій 3 об’єктом на позначення соматизма $є$ обов'язковість атрибутивного поширювача, то вихідною моделлю слід уважати таку: C - П- Atr - O; для конструкцій 3 відносно невідчужуваним об'єктом, відповідно, С - П - О.

Деривація на базі вихідних семантично елементарних речень відбувається у такий спосіб: Чоловік має ніс + Ніс є кривий - Чоловік, щзо має кривий ніс, некрасивий - Чоловік $з$ кривим носом некрасивий Кривоносий чоловік некрасивий - Кривоніс некрасивий [6, с. 115-117].

Зв'язок «посесор - фізичні складові тіла» є своєрідною моделлю, за якою людський менталітет структурує й інші типи відношень невідчужуваності. Так, типовою $є$ конструкція моделі $\mathrm{C}-$ П - О; $\mathrm{C}-\Pi$ - Atr - O та їі деривати на позначення особливостей, властивостей зовнішності представників флори й фауни. Наприклад: До мигдалевидних сортів належать форми, що мають вузькі, $з$ загостреною верхівкою плоди, подібні до горіхів мигдалю; Самка зимового п'ядуна має недорозвинені вкорочені крила, не літає, самець літає і має буруватосірі крила з темними поперечними хвилястими смугами. 
Нашу увагу привернули назви представників тваринного та рослинного світу. Назви можуть бути пов'язані із зовнішнім виглядом. Розглядувані флоро- та фаунолексеми являють собою складні назви, що передають партитивні відношення й позначають ціле за його характерною частиною. Твірна модель для дериватів має структуру $\mathrm{C}-\Pi-\mathrm{O}$; $\mathrm{C}-\Pi$ - Atr - O. Проте посесивні конструкції, що позначають особливості зовнішнього вигляду людини, представників флори й фауни на власне семантичному рівні мають різний склад семантичних компонентів посесивних відношень людина - тіло, що суттєво відрізняється від складу відношень рослина - будова; тварина - тіло. У групі назв виявлено певні закономірності. Зокрема, домінантною ознакою найменування $є$ форма та розміри рослин (тварин), які привертають до себе увагу людини своєю стереотипністю, або, навпаки, незвичайністю: а) флоролексеми: анограма тонколиста, астрагал мохнаткоквіткови, сон широколистий, булатка велико квіткова, булатка довголиста, фісташка туполиста, тонконіг різнобарвний; б) фаунолексеми: широконосі мавпи, довгоносі мавпи; довгоп 'ят, великорот, довгорил, широкорот, довгопер, гостроніс (риби).

Слід зазначити, що посесивні конструкції з посесором-істотою мають самодостатне комунікативне значення i за умови трикомпонентної структури. Про це свідчить закріпленість у мовному менталітеті унікальності ознаки як одночасно особливості і норми: а) мавпа має вуса вусатий тамарин; б) метелик має ніс - носатий метелик - носатка; в) риба має смуги на тілі - смугаста риба - оселедчевий смугач; птах має чуб - чубата синиия.

Друга особливість полягає в тому, що прикметник-дериват може мати різні значення (об'єктивно збільшеної ознаки чи унікальної ознаки) залежно від семантичного компонента посесивного значення за ознакою типовість / нетиповість, що проектується у процесі деривації у площину невідчужуваної посесивності: вухатий їжак (нетипова ознака) - вухатий біляк-заєиь (збільшена ознака).

Інша частина складних іменників-назв істот передбачає два семантично елементарних речення, у яких фігурують логічні відношення ототожнення посесивного об'єкта 3 пропозитивним суб'єктом номінативного речення: Птах має хвіст + Хвіст подібний до шила Птах, щзо має подібний до шила хвіст, красивий - Птах з подібним до шила хвостом, красивий - Птах з шилоподібним хвостом красивий Шилохвіст красивий.

При описі зовнішнього вигляду представників флори чи фауни активно використовуються деривати на зразок Птах з шилоподібним хвостом - Шилоподібний хвіст, що відображають зв'язок частина - иіле, наприклад: Суцвіття густе, багатоквіткове, яйцеподібно-циліндричне; Вона має веретеноподібне тіло, від середини хвостового плавия відходить довгий, за допомогою якого рибка розганяється. Назви на зразок 
шилохвіст указують на схожість форми тіла або окремих його частин 3 різними предметами або частинами тіла людини: а) флоролексеми: ремнепелюстник козячий, пальчатокорінник Фукса, зіркоплідник зірчастий; б) фаунолексеми: лопатоніс, лопатозуб, мішкотіл, шипоголов, американський веслоніс, трубкорот (риби).

Окрему групу утворюють іменники-назви істот, семантичну базу яких «становлять два однотипні семантично елементарні речення, що передбачають спільні компоненти, переважно предикат і аргумент-діяч» [6, с. 116-117]. За логікою реалізації посесивних відношень ці речення репрезентують операцію ототожнення форми всього тіла як цілого «посесора» істоти чи неістоти: Тварина подібна до вівціi + Тварина подібна до бика - Тварина подібна і до вівиі, $і$ до бика - Вівцебикоподібна тварина - Вівцебик; Риба має тіло + Тіло подібне до диска - Дископодібна риба Риба-диск. Назви вказують на подібність 3 предметами, істотами та неістотами: 1) робочими інструментами, зброєю (молот-риба, пила-риба, папірещь-риба, ніж-риба, меч-трава болотна); 2) інструментами (лірариба, дудка-риба, гітара-риба); 3) предметами (ліхтар-риба, ремінь-риба, ключ-риба, куля-риба); 4) ссавцями (птах-носоріг, риба-носоріг, рибамавпа, їжак-риба); 5) птахами (сичик-горобецьь, риба-колібрі, рибаластівка, риба-пелікан); 6) плазунами (змісрибка, риба-кайман, тюльпан змієлистий); 7) рослинами (мигдаль-персик, лавровишня).

Другою закономірністю є вибір ознаки за кольором, який покладено в основу найменування. Флоро- та фаунолексеми становлять деривати, що утворюються аналогічним ланцюжком: Рослина має извіт (квіти) + Цвіт $\epsilon$ білий - Рослина, щзо має білий цзвіт, красива - Рослина з білим цьвітом красива - Білоцвітна (білоквіткова) рослина красива - Білоцвіт (білоквіт) красивий. Наприклад: а) флоролексеми: білоиявіт весняний; крокус білоквітковий; любка зеленоцвітна; біловус стиснутий; жовтяниця червонолиста; б) фаунолексеми: червонокрила; сизокрила; синьоголовка.

В основу найменувань може буде покладена кількісна ознака, коли наявність певних частин тіла тварини чи складових частин рослини $\epsilon$ особливістю їхньої будови: а) флоролексеми: дріада восьмипелюсткова; зозулецьь тризубчастий; малаксис однолистий; любка дволиста; б) фаунолексеми: одноденний дзвонар; триголовка колючка; дев'ятиголкова колючка (риби); гадючий шестипелюстковий; згубниця n'ятилиста.

Деривати конструкцій органічної належності являють собою складні назви-композити, уживаються в конкретному й загальному значенні (прізвисько або прізвище). Пор.: сивоголовець, черевань, лобач, крутолоб, плосконіс, товстоніс, горбач, сиволап, жовтоног; I хоч як невесело було Бондаренкові. Та він зупинив недалекого, але спритнуватого жсовтодзьоба: -Tu, Стьопочко, не заблудився часом? (М. Стельмах). 
Інша ситуація спостерігається серед уживання дериватів, у яких посесором виступають неістоти (рослини) й істоти (тварини). 3 проаналізованих одиниць деривати на зразок широконоса мавпа, довгоп'ят. Це, очевидно, пояснюється тим, що унікальність, підкресленість ознаки посесорів-неосіб має широкий діапазон наявних рис, порівнюваних поміж однотипною сукупністю посесорів (рід, вид, підвид тощо): 1) кумка червоночерева - кумка жовточерева; одноусий дзвонар триусий дзвонар; сонечко семикрапкове - синявець червонокрапковий; 2) жсовтопуз (полоз); плосконіс; товстолобик (риба); чорногуз; тонкошийка; иироковух; білохвіст (nmax). У свою чергу, переважне використання субстантивного словосполучення свідчить про незакріпленість на мовному рівні розмежування за перцепційною системою (зоровою) унікальних ознак посесорів-істот. Пор.: довгоніг (комар) - довгоніжка (павук) - довгонога ракша (птах) - довгонога рогатка (кумка) - різнорівневі системи розвитку; білохвіст (орлан) білохвостий плавунчик (птах) - білохвостий трубач (птах) - однорівнева система розвитку. Незакріпленість розмежування фіксується як серед дериваційних ланок, так і серед значень суфіксів із посесивним значенням: вусатий - вусач: вусач альпійський, вусач дубовий (ряд жуки); губастий губань: смугач губастий, губань зелений (риби).

3 іншого боку, ознака частини тіла акцентується через порівняння серед обмеженої сукупності посесорів (ряд: вид, підвид, родина, рід). На фоні загальної сукупності посесорів виокремлена ознака не становить унікальної особливості. Така думка підтверджується оказіонально можливим дериватом у розмовно-побутовому стилі: сизокрила чайка сизокрилка; широкорота бородатка - широкоротка; жостір чорноягідний - чорноягідник; фіалка трицвітна - трицввітка.

Отже, дериваційна парадигма посесивних конструкцій зі значенням наявності в посесора фізичних властивостей i характерних ознак зовнішності визначає семантичні особливості залежно від опозицій абсолютна / відносна невідчужуваність; типовість, що проектується в ряди типовість - унікальність (для посесора-людини) і типовість - норма як неунікальність (для посесора-нелюдини).

Мовний матеріал дозволяє зробити узагальнення щодо типів мотивації українських назв представників флори i фауни як чинників концептуалізації в мовній картині світу.

Особливості категоризації класу тварин, птахів і рослин відображені в гіперонімічному й еквонімічному різновидах пропозиційної мотивації: перший різновид застосовує на позначення виду знаки його родових назв більш високого класифікаційного рівня (у науковій картині) світу - рангу ряду й родини; у наївній картині - базового рівня класифікації, згідно із твердженнями представників прототипної семантики). Наприклад, у номенклатурі ряд гагароподібних передбачає родину гагарових і види 
гагари червоношийої, чорношийої, білодзьобої. На прототип роду часто вказує мотиватор-корелятив, позначений в українських номенклатурних онімах прикметником на позначення усталеної ознаки - звичайний, що $\epsilon$ репрезентантом найбільш типових і яскравих ознак роду: зозуля звичайна, на відміну від зозулі чубатої, не має чубчика на голові. Використання корелятива для систематики онімів також демонструє найбільшу поширеність цього виду в Україні, на відміну від інших.

Еквонімічний різновид відображає вибір мотиватора назви виду 3 іншого класифікаційного видового рівня того самого класу; іншого класу. Так, відбувається перенесення назви горобцеподібних на орнітонім ряду совоподібних - сичик-горобець. Подібність із предметами, істотами, неістотами спостерігаємо в назвах пmax-носоріг, риба-носоріг, рибамавпа, їжак-риба, меч-трава болотна, лавровишня. Перенесення назви відбувається в межах ряду на назви видів кількох родин: ряд горобцеподібних має родини суторових (синиия вусата), довгохвостих синиць (синиця довгохвоста) і синицевих (ремез).

Мотиваторами українських онімів обираються предикатні терміни: складники рівнів якості (зеленяк, синьга, чорниш, гриф чорний), партитиви (норецьь чорношиїй, щирик червоногрудий, дятел білоспинний, рябок чорночеревий, сип білоголовий, червоноволик, синьошийка, чорногуз, орланбілохвіст).

На відміну від пропозиційного типу мотивації альтернативний їй асоціативний $є$ метафоричним за способом позначення структур знань про оніми в етносвідомості українського народу. Мотиватори $є$ донорськими й постачають власні знакові ресурси для фігурального позначення онімів.

Донорські концептуальні сфери обрані невипадково, адже використання їхніх знаків грунтується на численних асоціативних аналогіях зовнішних ознак, поведінки, життєдіяльності представників флори і фауни з іншими, більш близькими для номінаторів предметами i явищами дійсності та їхніми ознаками. Зокрема найбільш близькою для носіїв української мови сферою є концепт Людина. Номінатори, керуючись принципом антопометричності, сприймають й оцінюють оніми, установлюючи аналогії з назвами осіб за родом діяльності, властивостями людини, частинами iii тіла (соматизмами), знаками предикатів дій i поведінки людини тощо (пастушок; сова бородата; крячок білощокий; дятел трипалий; синиия вусата; лопатозуб; шипоголов; дрізд білобровий; чубарик; тесляр; ковалик). Механізмами появи знаків концепту Людина в асоціативній частині концепту оніми $є$ уподібненням на підставі суміжного компонента двох концептів, сценарних структур, образів, відчуттів.

Змішана мотивація представляе в ономасіологічних структурах українських онімів (композитів і сполук) різні за статусом фрагменти ментально-психонетичного комплексу, поєднуючи пропозиційні компоненти 3 асоціативними й модусними (серпокрилець білочеревий; 
шилодзьобка; корольок золотоголовий; реготун чорноголовий). Причому такі зв'язки в чотирикомпонентних ономасіологічних структурах орнітонімів можуть демонструвати поєднання кількох донорських концептуальних сфер із пропозиційним ядром концепту Тварина, Рослина, Птах (золотомушка жовточуба; пірникоза сірощока). Змішана мотивація зумовлена тенденцією до збагачення знакових ресурсів у сфері термінології за рахунок метафоризації.

Когнітивно-ономасіологічний аналіз українських флоро- і фаунонімів дав змогу виявити прототипну категоризацію концептів, складну систему гіперо-гіпонімічних відношень, установити базові пропозиційні компоненти, що фіксують відносно об'єктивну, несуперечливу інформацію в українській етносвідомості.

\section{Література}

1. Арутюнова Н. Д. Русское предложение. Бытийный тип. Структура и значение / Н. Д. Арутюнова, Е. М. Ширяев. - М. : Русский язык, 1985. - 195 с.

2. Безпояско О. К. Іменні категорії (функціональний аналіз) / О. К. Безпояско. К. : Наукова думка, 1991. - 177 с.

3. Безпояско О. К. Граматика української мови. Морфологія : [підручник] / О. К. Безпояско, К. Г. Городенська, В. М. Русанівський. - К. : Либідь, 1993. $336 \mathrm{c}$.

4. Бондарко А. В. Функциональная грамматика. Модальность. Посессивность / А. В. Бондарко. - Л. : Наука, 1984. - 133 с.

5. Городенська К. Г. Деривація синтаксичних одиниць / К. Г. Городенська. - К. : Наукова думка, 1991. - $189 \mathrm{c.}$

6. Камова И. М. Типология посессивного значения : автореф. дис. на соискание науч. степени канд. филол. наук / И. М. Камова. - М. : Изд-во МГУ, 1980. -27 с.

7. Колечко М. Д. Посессивные конструкции в украинском и русском языках : автореф. дис. на соискание науч. степени канд. филол. наук / М. Д. Колечко. К., 1995. $-25 \mathrm{c}$.

8. Терехова Д. І. Психолінгвістичні особливості сприйняття соматичної лексики в українській та російській мовах : автореф. дис. на здобуття наук. ступеня канд. філол. наук / Д. І. Терехова. - К., 1997. - 20 с.

9. Топоров В. Н. О некоторых предпосылках формирования категории посессивности / В. Н. Топоров // Славянское и балканское языкознание : Проблемы диалектологии. Категория посессивности. - М. : Наука, 1980. C. 142-167. 